\title{
Policy Alternatives to Reduce the Health and Economic Effects of Continued Asbestos Use in the Philippines
}

\author{
Romeo R. Quizon, ${ }^{1}$ Hilton Y. Lam, ${ }^{2}$ Jaifred Christian F. Lopez, ${ }^{2}$ \\ Marian Fe Theresa C. Lomboy ${ }^{1}$ and Ana Trinidad F. Rivera ${ }^{3}$
}

\begin{abstract}
${ }^{1}$ Department of Environmental and Occupational Health, College of Public Health, University of the Philippines Manila 'Institute of Health Policy and Development Studies, National Institutes of Health, University of the Philippines Manila ${ }^{3}$ Environmental and Occupational Health Office, Disease Prevention and Control Bureau, Department of Health
\end{abstract}

\begin{abstract}
Objectives. Asbestos is a carcinogenic mineral substance formerly used widely in the construction industry, all forms of which, except for chrysotile asbestos, have been banned in the Philippines. This article aims to propose policy alternatives to reduce the health and economic effects of continued asbestos use in the country.

Methods. Records of asbestos-related diseases, and asbestos industry-related data in the country were consolidated. The impact of continued asbestos use on the national economy were estimated incorporating natural mortality, regulations of the Department of Labor and Employment (DOLE), and concepts of multiplier effect and net present value. Round table discussions validated data and generated policy recommendations.
\end{abstract}

Results. Filipinos directly and indirectly exposed to asbestoscontaining materials (ACMs) are 5,289 and 30,000, respectively. The contributions of these groups to the national economy were estimated at PhP 1.08 Billion annually for workers directly exposed to ACMs and PhP 6.83 Billion annually for workers indirectly exposed. Two policy options-adjustment of threshold limit values, and a total ban—are presented.

Conclusion. A total ban on all forms of asbestos is shown to be the more cost-effective policy option for the country. It is recommended that government agencies, stakeholders in the asbestos industry, and the general public be involved in strategies for improving surveillance on asbestos exposure, increasing public awareness, and promoting the use of asbestos alternatives.

Key Words: asbestos, health policy, threshold limit values

Corresponding author: Romeo R. Quizon, MSc. Eng'g

Department of Environmental and Occupational Health

College of Public Health

University of the Philippines Manila

625 Pedro Gil Street, Ermita, Manila 1000 Philippines

Telephone: +632 5247102/+6325265966

Fax no.: +632 5237745

Email: rrquizon@up.edu.ph

\section{Introduction}

Asbestos is the commercial name given to naturally occurring fibrous mineral substances composed primarily of molecular chains of silicon and oxygen, and categorized under two mineral configurations: amphibole and chrysotile. Asbestos is known for its unique strength and resistance to fire. Because of these properties, these two forms of asbestos were widely used, especially in the late $19^{\text {th }}$ and early $20^{\text {th }}$ centuries, for various industrial purposes, especially construction, fireproofing, and insulation. ${ }^{1,2,3}$

Reports documenting the health effects of asbestos first surfaced in 1906, wherein H. Montague Murray described "an unusual fibrosis of the lungs." Subsequently, more cases of lung fibrosis, lung cancer and mesothelioma secondary to prolonged exposure to asbestos have been published. ${ }^{3}$ Among the two types of asbestos, it was amphibole asbestos whose pathogenicity was first described ${ }^{4}$ leading policy makers in various countries worldwide to ban the use of asbestos. Nonetheless, after political pressure from asbestosproducing countries, ${ }^{5}$ a significant number of countriesincluding the Philippines-still allow the importation and use of chrysotile asbestos, which has been presented as a "safer" $2,3,6$ form of asbestos.

However, more recent literature seems to disprove the "safety" of chrysotile asbestos. It has been shown that chrysotile asbestos is fetotoxic and teratogenic to mice, 7,8 deleteriously alters gene expression in human mesothelial cells, ${ }^{9}$ and produces changes in the cytoskeleton of human $\mathrm{T}$ cells ${ }^{10}$ leading to the promotion of tumor growth. In addition, retrospective $\mathrm{e}^{11}$ and prospective ${ }^{12,13}$ cohort studies suggest a causative relationship between prolonged chrysotile asbestos exposure and the development of lung cancer and gastrointestinal cancers.

As a result of the findings of these studies, there have been calls for a ban on the use of chrysotile asbestos. ${ }^{1,5} \mathrm{In}$ 2005, the World Health Assembly in its Resolution 58.22 urged Member States to pay "special attention to cancers from which avoidable exposure is a factor particularly exposure to chemicals [...] in the workplace and the environment."14 In 2012, the International Agency for Research on Cancer (IARC) unequivocally stated that there 
is sufficient evidence for the carcinogenicity of chrysotile asbestos to humans. ${ }^{15}$

Despite international concern on the continued use of chrysotile asbestos and other forms of asbestos, there has been no policy totally banning the importation and use of all asbestos-containing materials (ACMs) in the Philippines. While Administrative Orders from the Department of Environment and Natural Resources (DENR) may have prohibited the importation and use of some ACMs in the country, the use of ACMs in the Philippines remains uncurbed.

The continued use of ACMs in the country potentially exposes individuals to asbestos and putting them at risk of developing asbestos-related diseases. These diseases, in turn, represent significant economic burden, both for families and the national economy. Policy options are needed to identify the alternatives to mitigate the health and economic effects of continued asbestos use in the country, in terms of costeffectiveness and impact on the national economy and on public health.

\section{Materials and Methods}

A literature search of the MEDLINE and PubMed databases, and an online search of existing policies on asbestos importation and use were done. Among the keywords used were "asbestos", "chrysotile asbestos", and "asbestos use policies in the Philippines." Only articles in English were included in the search. In addition, data from 2007 to 2011 were also gathered from the Department of Health (DOH), Department of Labor and Employment (DOLE), National Statistics Coordinating Board of the Philippines (NSCB) and the U.S. Geological Surveys.

Data gathered from these agencies document the annual estimated consumption of asbestos in the country, in terms of its use in various construction materials. These policies and evidence on asbestos use were examined and the implications of these policies to the country's economy and to public health were analyzed.

In order to provide an estimate of the effects of continued asbestos exposure on the national economy, we made use of the concept of the multiplier effect. The multiplier effect was defined by Dumaua ${ }^{16}$ as a measure of the effect of a particular "external change" on total economic activity in a given community or country, through respending within that economy. Examples of these "external changes" are new investments, income generation, and the putting up of new businesses. This concept therefore predicates that every one peso that is generated as income contributes a multiple of its value to the national economy. ${ }^{16}$ This multiplier varies across economic sectors. For the purposes of this article, the multiplier for the manufacturing sector was used. Net present value was also computed to take into account inflation rates and the projected economic effect beyond one year, over a 20-year period. For the purposes of estimation, the average inflation rate of $3.8 \%$ from the years 2007 to 2014 was used. ${ }^{17}$

In addition, round table discussions were also organized to gather policy recommendations from various stakeholders. These stakeholders include the $\mathrm{DOH}-$ Environment and Occupational Health Office, DOH-Disease Prevention and Control Bureau, the Department of Environment and Natural Resources (DENR)-Environment Management Bureau, the Department of Labor and Employment (DOLE)-Bureau of Working Conditions, the DOLE-Employees' Compensation Commission, the DOLEOccupational Safety and Health Center, the Department of Science and Technology-Industrial Technology Development Institute, the Lung Center of the Philippines, Bureau of Customs and the Association of Chrysotile Industries of the Philippines. Representatives from the University of Occupational and Environmental Health, Japan and the World Health Organization were also consulted.

\section{Results}

\section{Policies on asbestos use in the Philippines}

The use of asbestos in the country was initially encouraged in response to a provision included in Section 2.02.02 of Republic Act 6541 or the National Building Code of the Philippines enacted in 1972 and amended in 1977, which specifies that building materials must have a "one hour fire-resistive time period rating." 18,19 Since asbestos is the least expensive option for a material with these properties, asbestos became widely used in the country.

The growing awareness on occupation-related diseases prompted the Department of Labor and Employment (DOLE) to enforce standards for allowable occupational exposure to various substances, including asbestos. In 1989, DOLE mandated in its Occupational Safety and Health Standards the reporting of work-related health issues, including disease conditions which may be attributable to occupational exposure to various substances, including asbestos. ${ }^{20}$

Despite this increasing awareness of national agencies on asbestos-related diseases, there was no significant effort of any government agency in the Philippines to document the status of asbestos use in the country, the total population exposed to asbestos-containing materials (ACMs), and buildings in which ACMs were used.

In 1998 the International Programme on Chemical Safety (IPCS), due to mounting scientific evidence on the adverse health effects of asbestos, encouraged "countries that do not have established policies for the control of hazards related to the presence of asbestos in the environment should develop guidelines for this purpose."21 Subsequently, the Philippine government enacted Republic Act 6969, otherwise known as the "Toxic Substances and Hazardous 
Wastes and Nuclear Wastes Control Act of 1990." This law mandated the Department of Environment and Natural Resources to formulate and maintain a list of toxic substances and hazardous wastes that can be found in the country. In addition, the Employees' Compensation Commission (ECC), an agency under the DOLE, approved asbestosis as a compensable work related disease. ${ }^{22}$

In 2000, asbestos was included in DENR Administrative Order (DAO) 2000-02, thereby banning the use of amphibole asbestos while allowing the limited use and controlling the disposal of chrysotile asbestos in the country. ${ }^{23}$ Asbestos continues to be listed in the revised chemical list. ${ }^{24}$ Moreover, the DENR has also issued regulations detailing the proper handling and disposal of asbestos and asbestos containing wastes. ${ }^{25}$ Currently, the DENR limits the use of chrysotile asbestos to these high density products:

1. Fire proof clothing

2. Roofing felts or related products

3. Asbestos cement roofing

4. Asbestos cement flat sheet

5. Friction materials

6. High temperature textile products

7. Gaskets

8. Mechanical packing materials

9. High grade electrical paper

10. Battery separators

11. Other high density products

Moreover, the same document specifically prohibits the use of all forms of asbestos in the following products:

1. Toys manufacturing

2. Pipes and boiler lagging manufacturing

3. Low density jointing compounds

4. Corrugated and commercial paper

5. Untreated Textiles

6. Flooring felts and covering

7. Rollboard

8. Specialty paper

9. Other low density products ${ }^{23}$

Therefore, despite international calls for a total ban on all types of asbestos, until this time the Philippines has not officially banned the use of all asbestos-containing materials.

Recent data from the United States Geological Survey (2011) do not demonstrate a significant decrease in the use of asbestos in the Philippines. ${ }^{26,27}$ The trend on the consumption of asbestos in the country since 2003 can be seen in Figure 1.

\section{Asbestos-related diseases in the Philippines}

Between 1997 to 2012, a total of 482 asbestos-related diseases (ARD) were reported by various agencies and institutions in the country.

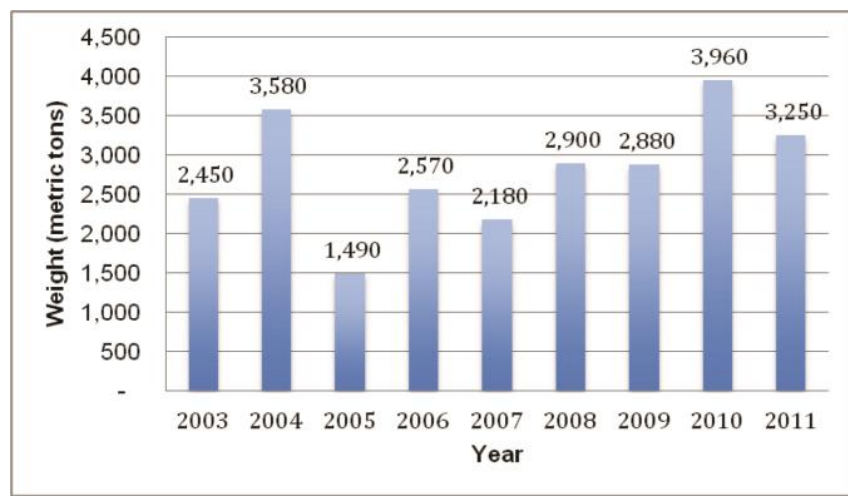

Figure 1. Annual estimated consumption of asbestos, Philippines, 2003-2011 (U.S. Geological Survey, Note: Consumption $=$ production minus exports, plus imports)

Table 1. Reported cases of asbestos-related diseases (ARD) per agency

\begin{tabular}{lcc}
\hline \multicolumn{1}{c}{ Agency (year) } & ARDs & Number \\
\hline $\begin{array}{l}\text { Lung Center of the Philippines - DOH } \\
\text { (2000-2012) }\end{array}$ & Mesothelioma & 11 \\
$\begin{array}{l}\text { Philippine Cancer Society (2000-2012) } \\
\text { Social Security System (SSS) 2012 }\end{array}$ & $\begin{array}{l}\text { Mesothelioma } \\
\text { Mesothelioma }\end{array}$ & 33 \\
$\begin{array}{l}\text { Lung Center of the Philippnes - DOH } \\
\text { (2000-2012) }\end{array}$ & Asbestosis & 387 \\
$\begin{array}{l}\text { Subic Naval Facilities (Lung Center of } \\
\text { the Philippines - DOH, 2000-2012) }\end{array}$ & Asbestosis & 12 \\
$\begin{array}{l}\text { Trade Union Congress of the } \\
\text { Philippines (TUCP, 1997-2003) }\end{array}$ & Asbestosis & 19 \\
Social Security System (SSS), 2012 & Asbestosis and & 19 \\
\multicolumn{1}{c}{ Total } & related diseases & \\
\hline
\end{tabular}

This relatively small number of cases must be analyzed in relation to the natural disease progression of asbestosrelated diseases, as well as the lack of available data on the prevalence of asbestos-related diseases in the Philippines. ${ }^{28}$ Asbestos is slow in exerting its pathogenic effects on the human body, in that it takes 10 to 40 years of inhalation before such catastrophic health conditions manifest. These long-delayed sequelae often go undetected as follow-up diagnostic tests are seldom carried out on patients who have been diagnosed with asbestos-related diseases. ${ }^{29,30}$

Because of the long latency of ARDs, it may be argued that victims of asbestos-related diseases would die within their expected lifespans. However, costs for diagnosis, treatment and palliative care, which may range between $\mathrm{PhP}$ 1 million to 5 million per year per patient, ${ }^{31}$ may impoverish the families of these victims. 


\section{Discussion}

Economic contribution of workers of asbestos processing companies

Chrysotile asbestos used in the Philippines is mostly imported from Canada, Eastern Europe and Russia and is processed by 143 companies nationwide. These asbestosprocessing companies employed a total of 5,289 workers in $2012 .{ }^{32}$ Assuming a natural mortality of $0.4335 \%$ per year ${ }^{33}$ and a 20-year productive life, 5,086 of these workers are expected to be still alive after 10 years, and 4,870 after 20 years. In its annual report, DOLE reports an average daily wage rate for workers and laborers under the category "trades and related workers" of PhP 312.11 a day or $\mathrm{PhP}$ $81,148.60$ a year for 260 working days. ${ }^{34}$ We can therefore assume that each year, these workers collectively earn $\mathrm{PhP}$ 429 million on the first year, PhP 414 million at year 10, and PhP 395 million at year 20.

In order to provide an estimate of how much these exposed workers contribute to the national economy, we also take into account daily wage rates mandated by DOLE, and the concepts of multiplier effect and net present value. The concept of multiplier effect predicates that every one peso that is generated as income contributes a multiple of its value to the economy. ${ }^{16}$ This multiplier varies across various economic sectors and includes various aspects of contribution to the national economy. For the manufacturing sector, of which asbestos workers are part, this multiplier has been computed as 3.759418. This means that for every $\mathrm{PhP} 1$ earned by workers in the manufacturing sector, $\mathrm{PhP}$ 3.76 is contributed to the national economy. ${ }^{16}$ Therefore, taking into account the multiplier effect, these 5,289 exposed workers contribute an estimated PhP 1.6 billion to the national economy every year. At year 10, it is estimated that this amount will become PhP 1.56 billion, and at year 20, PhP 1.49 billion. The nominal value of the total estimated contributions to the economy of these workers over 20 years is PhP 30.98 billion.

However, the aforementioned values do not yet take into account inflation. Taking into account inflation, which for this purpose we use the 2007-2014 average inflation rate of $3.8 \%,{ }^{17}$ it can be estimated that they would contribute $\mathrm{PhP}$ 21.54 billion to the national economy in their lifetimes, or PhP 1.08 billion annually over 20 years.

Economic contribution of workers in asbestos downstream companies

In addition, an estimated 30,000 workers in downstream companies that use these products are likewise at risk of developing asbestos-related diseases. ${ }^{30}$ These workers are mainly office employees, seafarers, and car maintenance workers, construction workers, among other occupations. For the purposes of estimation, we shall make use of the average daily wage rate for all occupations in the Philippines, which is PhP 349.16 a day, ${ }^{34}$ or PhP 90,781.60 per year. Collectively, these 30,000 exposed Filipinos earn an estimated PhP 2.72 billion a year. Majority of these exposed workers are also in the manufacturing sector. Applying the multiplier effect for the manufacturing sector illustrated previously, the estimated annual contribution of this exposed population to the national economy is $\mathrm{PhP} 10.24$

Table 2. Asbestos workers: projected working age population, total annual income, and contribution to the national economy, 2014 base year

\begin{tabular}{lrr}
\hline & \multicolumn{1}{c}{ Year 1 } & \multicolumn{1}{c}{ Year 10 } \\
\hline Est. working age population (20-64 years old) & 5,289 & 5,086 \\
Est. total annual income, PhP & $429,194,945$ & $414,532,726$ \\
Est. contribution to economy (multiplier effect), PhP & $1,613,523,203$ & $1,558,401,793$ \\
Nominal value of total estimated contribution to economy (Year 1 to 20) & $30,975,282,243$ \\
Net present value, PhP & $21,540,429,991$ \\
Annualized net present value, PhP & $1,077,021,500$ \\
\hline (Note: Est. annual natural mortality rate 0.4335\%. Est. total annual income computed for PhP 312.11 x 260 working days per year. Multiplier used for & \\
contribution to economy is 3.759418. Total net present value computed from year 1-20, computed at 2007-2014 average inflation rate of 3.8\%.)
\end{tabular}

Table 3. Workers indirectly exposed to asbestos: projected working age population, total annual income, and contribution to the national economy, 2014 base year

\begin{tabular}{|c|c|c|c|}
\hline & Year 1 & Year 10 & Year 20 \\
\hline Est. working age population (20-64 years old) & 30,000 & 28,850 & 27,623 \\
\hline Est. total annual income, $\mathrm{PhP}$ & $2,723,448,000$ & $2,619,005,073$ & $2,507,648,264$ \\
\hline Est. annual contribution to economy (multiplier effect), PhP & $10,238,579,433$ & $9,845,934,815$ & $9,427,298,020$ \\
\hline Nominal value of total estimated contribution to economy (Year 1 to 20) & & $196,553,038,145$ & \\
\hline Net present value at $3.8 \%$ inflation rate, $\mathrm{PhP}$ & & $136,684,370,602$ & \\
\hline Annualized net present value, $\mathrm{PhP}$ & & $6,834,218,530$ & \\
\hline
\end{tabular}


billion each year and a 20-year total nominal value of $\mathrm{PhP}$ 196.55 billion. Assuming a 20-year productive life for these 30,000 workers, a natural mortality of $0.4335 \%$ per year, ${ }^{33}$ and the 2007-2014 average inflation rate of $3.8 \% 17$ it can be estimated that they would contribute PhP 136.68 billion to the national economy in their lifetimes, or $\mathrm{PhP} 6.83$ billion annually over 20 years.

The aforementioned figures do not include the Filipinos who continue to be exposed to asbestos by living and/or working in asbestos containing spaces nationwide. The 2000 national housing census data from the National Statistics Office show that a total of 8,823 occupied housing units have outer walls fitted with ACMs and 57,300 housing units have roofs that are made of "asbestos/others". ${ }^{35}$ Moreover, records from the Philippine Homesite and Housing Association (PHHC) show that an unspecified number of houses fitted with roofs made of asbestos were built in various cities nationwide starting in the 1940s, until 1975, when asbestos roofing became prohibited. ${ }^{36}$ Since the structures built during this period would now have started deteriorating, these structures would be expected to release asbestos fibers into the surrounding environment, exposing bystanders to the risk of potentially developing asbestos-related diseases.

\section{Policy turning point}

With mounting international evidence on the carcinogenicity of chrysotile asbestos ${ }^{1,4-5,7-13}$ despite being touted as a "safer" form of asbestos, there exists a window of opportunity for the Philippines to include the banning of all chrysotile asbestos in the country. With the current focus on universal health care of the Aquino Administration, the Philippines cannot afford to ignore these estimated 35,000 Filipinos who annually contribute a total of $\mathrm{PhP} 7.91$ billion to the national economy to suffer incurable and fatal illhealth due to preventable occupational hazards. We therefore present two policy options that take into account the health and economic implications of continued asbestos use in the country.

\section{Option 1: Adjusting the allowable threshold value limits}

Asbestos exposure is currently measured in the Philippine occupational setting through threshold limit values (TLVs) or permissible exposure limits (PELs). These units were developed by the American Conference of Governmental Industrial Hygienists (ACGIH) and were adopted by the Occupational Safety and Health Center (OSHC) of the Philippines. They have been adopted as "health-hazard thresholds for exposure to chemical and mineral substances." ${ }^{37}$ Rule 1070 of the Occupational Safety and Health Standards used by DOLE in the Philippines specifies that the air quality standard for asbestos exposure in all forms shall be " 2 fibers/cc, 5 micrometers in length." 20 However, a more updated standard used by the United
States Occupational Safety and Health Administration is 0.1 fiber/cubic centimeter. ${ }^{38}$

These units of exposure allow policy makers to set limits to occupational exposure of asbestos. The determination of these units, however, has been put into question in the international community for "lack of scientific rigor, inadequate medical input, and lack of attention to financial conflicts of interest".39,40 This therefore casts doubt on whether or not these standards indeed safeguard workers and other exposed individuals from disease-causing levels of exposure to asbestos. In addition, further research on more realistic TLVs and PELs may be very costly in relation to the expected outcomes. As such, the cost-effectiveness of identifying safer TLVs/PELs may be too expensive. Moreover, if the TLVs and PELs are indeed lowered eventually, new investments in more sophisticated testing machines may be necessary. In addition, new training may need to be undertaken by technicians for these more sensitive testing machines, adding more cost to this option.

\section{Option 2: Total ban}

Another policy option is enacting a total ban of all forms of asbestos. This policy option shall impact the 143 manufacturers and processing companies of chrysotile asbestos in the Philippines, and may bring unemployment to its 5,289 workers. Nonetheless, as illustrated above, the expected economic loss of these companies would be small in relation to the prevented societal cost to the national economy ( $\mathrm{PhP} 1.08$ billion vs. PhP 6.83 billion annually). Furthermore, the presence of viable alternatives would lessen the financial loss of current chrysotile asbestos manufacturers, processors and their workers to even lower levels, since these companies may be given incentives to switch to safer alternatives or raw materials. A total ban on all asbestos including chrysotile asbestos may be even more prudent as a national policy, because the main beneficiaries of this total ban would be the productive age working class, and because it would enhance public health and public trust. As current national regulations already mandate governmental compensation for ARDs, a total ban on all forms of asbestos would not present a moral dilemma. A total ban on all forms of asbestos would also give clarity on the contribution of chrysotile asbestos to ARDs.

Efforts have been made to enact such a ban on a national scale. In 2011, two separate House of Representative Bills were filed: House Bill (HB) 479, which was filed by Representative Kaka Bag-ao; and HB 896, which was filed by Representative Raymond Democrito Mendoza, which allows a three year grace period for total ban of all asbestos and asbestos containing products. ${ }^{28}$ In 2013, a combined version, now known as House Bill 2638 was re-filed by Representative Raymond Democrito Mendoza. 


\section{Conclusion}

Despite the paucity of data on health statistics and economic burden, this paper presents compelling argument that a total ban on all forms of asbestos, including chrysotile asbestos, is a logical and cost-effective national policy for the Philippines. This is due to the fact that the health consequences of asbestos exposure is fatal, irreversible, and financially catastrophic, while the number of affected manufacturers/processors are only 143, and the impact on these companies can be lowered because of the presence of safer alternatives or raw materials. It is also recommended that a regular monitoring and evaluation program with databanking be instituted and appropriately funded for regional offices of the DOLE Bureau of Working Conditions, and research institutions.

\section{Recommendations}

The experience of this research yielded the following challenges in forming recommendations for policy on asbestos: unavailability and inaccessibility of data; limited number of epidemiological studies on ARDs; low population risk due to existing high standards; poor health surveillance; lack of capability to conduct exposure assessment in informal sectors (e.g. unregistered car repair shops, etc); and lack of education and awareness of public and workers on the hazards of asbestos, including chrysotile asbestos. These issues are expected to continue to plague asbestos control in the country no matter what policy option is undertaken, if no improvement in monitoring and evaluation is implemented.

In response to gaps recognized in the current policies on asbestos exposure, there should be a mechanism for regular monitoring and surveillance by DOLE offices nationwide, and work environment measurement (WEM) testing by OSHC inspectors. Increased data banking should also be implemented to improve information access of annual exposure data reports (AEDRs) and annual medical reports (AMRs). In addition, more government funding for research on ARDs, review of current standards, and public education and awareness must be considered. ${ }^{41,42}$

Whatever the policy option, the ECC, OHSC, the Lung Program of the DOH, and the DENR need to update its definition of asbestosis related illness to include chrysotile asbestos-based effects. Furthermore, workers and the general public need to be made aware of their possible exposure to asbestos, not only in their workplaces, but also in the public places where they play and find recreation with their families, as well as in the homes that they live in. Finally, current stakeholders in the asbestos industry must be encouraged to use safer asbestos alternatives, in order to sustainably eliminate the need of the industrial sector to use asbestos. ${ }^{41,42}$

\section{Acknowledgments}

The authors wish to acknowledge the Department of Health for providing necessary funding and technical support for this study; and to Ms. Madeline B. Dumaua of the Statistics Research and Training Center for her valuable inputs.

\section{References}

1. Collegium Ramazzini. Asbestos is still with us: Repeat call for a universal ban. Am J Ind Med. 2011; 54(2):168-73.

2. Alleman J, Mossman B. Asbestos revisited. Scientific American. 1997; 7075.

3. Murray R. Asbestos: a chronology of its origins and health effects. Br J Ind Med. 1990; 47(6):361-5.

4. Stanton M, Layard M, Tegeris A, et al. Relation of particle dimension to carcinogenicity in amphibole asbestoses and other fibrous minerals. J Natl Cancer Inst. 1981; 67(5):965-75.

5. LaDou J, Castleman B, Frank A, et al. The case for a global ban on asbestos. Environ Health Perspect. 2010; 118(7):897-901.

6. Yarborough C. Chrysotile as a cause of mesothelioma: an assessment based on epidemiology. Crit Rev Toxicol. 2006; 36(2):165-87.

7. Fujitani T, Hojo M, Inomata A, et al. Teratogenicity of asbestos in mice. J Toxicol Sci. 2014; 39(2):363-70.

8. Pylev L, Vasil'eva L, Smirnova O, et al. [Carcinogenic and mutagenic activity of chrysotile, processed with iron chloride (III)] Gig Sanit. 2013; (4):76-80.

9. Qi F, Okimoto G, Jube S, et al. Continuous exposure to chrysotile asbestos can cause transformation of human mesothelial cells via HMGB1 and TNF-a signaling. Am J Pathol. 2013; 183(5):1654-66.

10. Maeda M, Chen Y, Kumagai-Takei N, et al. Alteration of cytoskeletal molecules in a human $\mathrm{T}$ cell line caused by continuous exposure to chrysotile asbestos. Immunobiology. 2013; 218(9):1184-91.

11. Mirabelli D, Calisti R, Barone-Adesi F, Fornero E, Merletti F, Magnani, C. Excess of mesotheliomas after exposure to chrysotile in Balangero, Italy. Occup Environ Med. 2008; (65):815-9.

12. Wang X, Yano E, Lin S, et al. Cancer mortality in Chinese chrysotile asbestos miners: exposure-response relationships. PLoS ONE. 2013; 8(8).

13. Wang $X$, Lin S, Yano E, et al. Mortality in a Chinese chrysotile miner cohort. Int Arch Occup Environ Health. 2012; 85(4):405-12.

14. World Health Assembly. Resolution 58.22 [Online]. 2005 [cited 2014 April]. Available from http://www.who.int/ipcs/publications/ wha/cancer_resolution.pdf?ua=1.

15. International Agency for Research on Cancer. Arsenic, metals, fibres and dusts. Volume $100 \mathrm{C}$, A review of human carcinogens. Lyon, France: IARC, World Health Organization, 2012.

16. Dumaua MB. Input-output multiplier analysis for major industries in the Philippines. National Statistics Coordination Board, Philippine Statistics Authority [Online]. [cited 2014 Nov]. Available from http://www.nscb.gov.ph/ncs/11thNCS/papers/invited\%20papers/ips02/02_Input-Output\%20Multiplier\%20Analysis\%20for\%20Major \%20Industries\%20in\%20the\%20Philippines.pdf.

17. National Statistical Coordination Board (NSCB). Consumer price index for all income households and headline inflation rates, January 2004 October 2014. NSCB, Philippine Statistics Authority [Online]. [cited 2014 Nov]. Available from http://www.nscb.gov.ph/secstat/d_price.asp.

18. Congress of the Republic of the Philippines. An act to ordain and institute the national building code of the Philippines (Republic act no. 6541), 1972.

19. Republic of the Philippines. Adopting a national building code of the Philippines (NBCP) thereby revising Republic Act numbered sixty-five hundred forty-one (Presidential decree no. 1096), 1977.

20. Department of Labor and Employment (DOLE). Occupational safety and health standards, as amended, 1989. Manila: DOLE, 1989, 338 pp. 
21. International Program on Chemical Safety. Report of an IPCS Working Group Meeting on the Reduction of Asbestos in the Environment, Internal Technical Report. Rome, Italy, 12-16 December 1988 [Online]. [cited 2014 April]. Available from http://www.chrysotile.com/ en/sc_publi/ipcs_report.aspx\#6.

22. Employees' Compensation Commission (ECC). Resolution 96-08-0372. Manila: ECC, Department of Labor and Employment, 1996.

23. Department of Environment and Natural Resources (DENR). Department Administrative Order no. 02, series of 2000.

24. DENR Department Administrative Order no. 2005-27.

25. DENR Department Administrative Order no. 2004-36.

26. United States Geological Survey (USGS). World asbestos consumption from 2003 through 2007. Mineral industry surveys. Reston, Virginia, USA: USGS, 2007, p. 2.

27. Virta, R. Asbestos. 2012 minerals yearbook. Reston, Virginia, USA: USGS; 2013. pp. 8.1-8.7.

28. Enoveso A, Gaela MA. Consultative meeting for the development of a national program for the elimination of asbestos-related diseases in the Philippines. Meeting minutes. Manila: College of Public Health, University of the Philippines Manila. 6 September 2012.

29. O'Reilly K, McLaughlin A, Beckett W, Sime PJ. Asbestos-related lung disease. Am Fam Physician. 2007; 75(5):683-5.

30. Diaz D. Asbestos-related diseases in the Philippines: the Lung Center of the Philippines asbestos screening program. Acta Med Philipp. 2009; 43(3):65-9.

31. Lam H, Mendoza VA, Mendoza BT. Cost of five cancers in the Philippines. 2010. Unpublished.

32. Icamina P. PH continues to import asbestos. Malaya Business Insight [Online]. 2014 Jan 7 [cited 2014 July]. Available from http://www.malaya.com.ph/business-news/business/ph-continuesimport-asbestos.

33. Tayag EA, Benegas-Segarra A, Sinson F, et al. The 2010 Philippine Health Statistics. National Epidemiology Center, Department of Health (Philippines) [Online]. [cited 2014 Nov]. Available from http://www.doh.gov.ph/sites/default/files/PHS2010_March13.pdf.

34. Department of Labor and Employment. Table 22 - Average daily basic pay of wage and salary workers by major occupation group, Philippines: 2012 - January 2014 [Online]. [cited 2014 Nov]. Available from http://www.bles.dole.gov.ph/PUBLICATIONS/Current\%20Labor \%20Statistics/STATISTICAL\%20TABLES/PDF/Tab22.pdf.

35. National Statistics Coordination Board (NSCB). Census on Population and Housing. Manila: NSO, Philippine Statistics Authority [Online]. 2000 [cited 2014 April]. Available from http://www.nscb.gov.ph/ secstat/d_popn.asp.

36. Villanueva M, Granadillos N, Cucueco, M, et al. Asbestos in the Philippines: country report. Quezon City, Philippines: Occupational Safety and Health Center, 2004, pp. 70-75.

37. Rappaport $\mathrm{S}$. Threshold limit values, permissible exposure limits, and feasibility: the bases for exposure limits in the United States. Am J Ind Med. 1993; 23(5): 683-94.

38. Occupational Safety and Health Administration (OSHA). Asbestos (all forms). In: Chemical sampling information. United States Department of Labor [Online]. [cited 2014 April]. Available from https://www.osha.gov/dts/chemicalsampling/data/CH_219600.html.

39. Ziem G,Castleman Bl. Threshold limit values: historical perspectives and current practice. J Occup Med. 1989; 31(11):910-8.

40. Castleman B. Asbestos: medical and legal aspects. Aspen, New York, USA: Aspen Publishers; 2005. p. 225.

41. Enoveso, Gaela MA. Consultative meeting for the development of a national program for the elimination of asbestos-related diseases in the Philippines. Meeting minutes. Quezon City: Lung Center of the Philippines. 4 October 2012.

42. Enoveso A, Gaela MA. Consultative meeting for the development of a national program for the elimination of asbestos-related diseases in the Philippines. Meeting minutes. Manila: Environment and Occupational Health Office, Department of Health. 18 October 2012. 